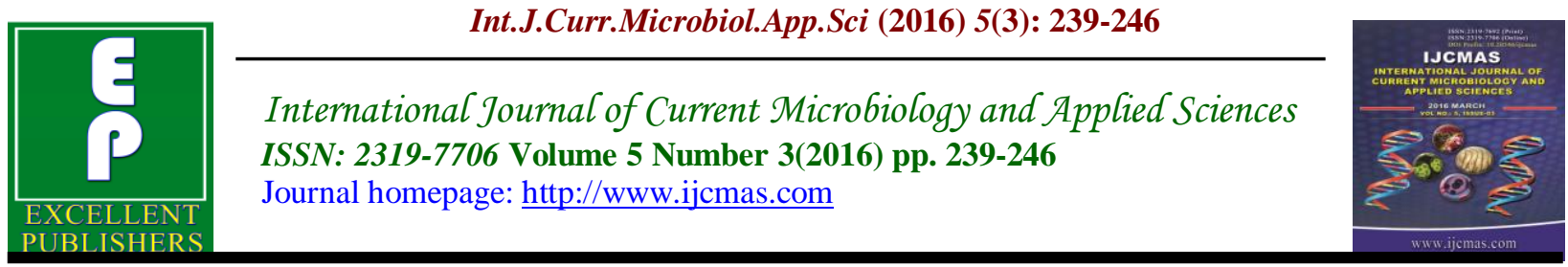

Original Research Article

http://dx.doi.org/10.20546/ijcmas.2016.503.029

\title{
Study of Some forms of IBA in the Rooting Process of the Olive
}

\author{
Hairi Ismaili* \\ Agricultural University of Tirana, Albanian Gene Bank, Str.Siri Kodra 1020 Tirana, Albanie \\ *Corresponding author
}

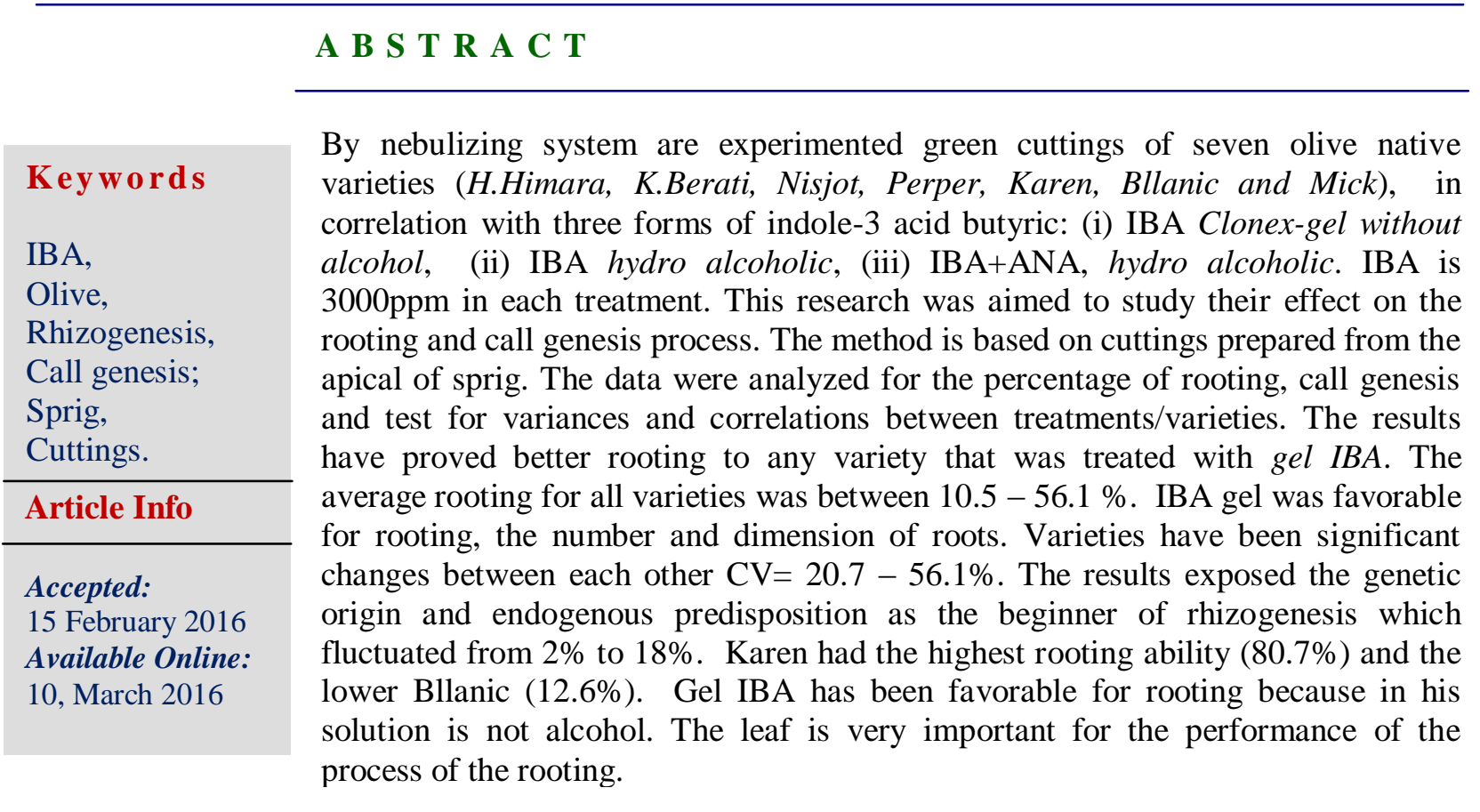

\section{Introduction}

Through the Project of FAO and IAM-BariItaly at the Institute of Olive Research, there was a modern system for the propagation in Vivo and in Vitro. At present, Albania has 60 thousand hectares of olive grower and 12 million olive trees, out of which 1.6 million olive trees are centenarians, 500-3000 years Ismaili, et al. (2014).

Many researchers have been realized but, the efficiency of multiplication is influenced by different factors such as endogenous hormonal stimulants Fiorino, (1980); Daoud, et al. (1989). The use of treatments auxins, mainly Indole-3 Butyric Acid, allowed standardize the technique and identify alternative methods Fabbri, (1980), with a relative constancy in the results achieved only if conditions remain unchanged pick Caballero, (1993), if one takes proper account of the phonological phases of the material subjected to rooting Loreti, et al. (1964), age and condition of the mother plants Bartolini et al. (1989), all factors that play a role too often not 
adequately assessed by the operators. This adds to the variability determined by different and often little-known ability rhizogena in many cultivars that characterize the current standard Albanian and the mode of administration of the treatments more efficacy, resulting auxins poorly soluble in water and also in hydro alcoholic mixtures soggente limits concentration Berthon, (1993). The use of hormones is studied by many authors, as Hartmann, et al. (1952), Rodríguez, et al. (2008); Fernandes-Serrano, et al. (2002) etc, where they provide information about the effects of rooting of olive vegetative cuttings, with different ways. But the, application of the plant hormone has many aspects for solution, for example; the chemical nature, the dose concentration, retention time in solution, combination with other substances, treatment conditions, etc. The individual genetic ability is another aspect important, especially for varieties resulting difficult. This scientific work has determined the effect of three forms of IBA, in relation with some olive varieties which have the ability to lower rooting.

\section{Material and Methods}

\section{Description of the method}

Parent trees belong to the seven varieties, named: H.Himara, KBerati, Nisjot, Perpen, Karen, Bllanic and Mick. The age of the plants was about 50 years. Two varieties, HHimara and Bllanic were from Vlora; three varieties, Mick, Karen and Perper from Tirana and two varieties of Berat. The trees were not irrigated. The sprigs were taken for the experiment, on March 20, 2014. Green pieces of $8-12 \mathrm{~cm}$, with two pairs of leaves they are prepared from the top of sprig (apical). Search variants were: (i) indole-3 butyric acid $\left(\mathrm{C}_{13} \mathrm{H}_{12} \mathrm{NO}_{2}\right)$ dose 3000ppm, hydro alcoholic solution, (ii)
Clonex gel 3000ppm, IBA/ANA $\left(\mathrm{C}_{12} \mathrm{H}_{10} \mathrm{O}_{2}\right)$ hydro alcoholic solution. It was used 100 pieces / Treatment random, 4 repeats. The pieces are treated 6 seconds. In each experiment only one treatment (Control) was applied as a probative. In any hydroalcoholic concentration: alcohol comprises 20-24\% and $\mathrm{H}_{2} \mathrm{O}, 80-76 \%$. The cuttings were planted in a nebulizing bank with perlite substrate. The temperature within the banks' area was preserved $18^{\circ} \mathrm{C}\left( \pm 1^{\circ} \mathrm{C}\right)$, whereas in the substrate $24^{\circ} \mathrm{C}\left( \pm 1{ }^{\circ} \mathrm{C}\right)$, realized through a furnace with a boiler, two pumps, two Thermostats, Flu stats and other equipment of control Ismaili, (2010).

The nebulization was done for 5-7 seconds in each $15 \mathrm{Wh} / \mathrm{m}^{2}$, in function of the active solar radiation. The module of the solar integrator was automatic through a solar integrator SI-20. Research Indices: at the end of the rooting process, the evaluated indices were: (i) rooting percentage, (rooted cuttings expressed in \%). (ii) Callus total percentage, (iii) Defoliation percentage evaluated for each cultivar in $\%$, the number of the primary roots extracted over 10 cuttings for each repetition, the number of the secondary roots and the length of primary roots.

\section{Statistical Analysis}

Sample data are modeled, is realized descriptive analysis for the variance, Stand Dev, test variability, correlations by JMP software Jmp, SAS (2008).

\section{Results and Discussion}

Morphological changes: Morphological and physiological exchanges were controlled for the temperature of substrate and environment and for air humidity through mist propagation method. During the 20 first days in the bank of fog, were developed 
morphological changes, cicatrisation of the wound, rapid cellular multiplication and enlarge volume of cells. At the bottom, on both sides of sclerenkimatic ring is forming a bulge in milk color, which called callus. In the third week, simultaneously by callus starts the root meristem, which differs in the fourth week - the fifth. After the lesion was healed on both sides of the sclerenchemical ring we notice augmentation of the cortical parenchyma and phloem and numerical increase, which are later transformed into a mass of hyperplastic tissues. The differentiation of radices originates from a cell of the primary and secondary ray pith in the area where these are bred with the cambial stratum. In this case one of the parenchymatous, full of vacuoles, found in the area between two conductive clusters is enriched with plasma, regains the function of meristematic cells and starts division rapidly, thus forming a great number of rooting cells which are differentiated from the inside and outside. After eight weeks the roots are completely formed, they have brown-ocher and they have finalized their status in correlation with the treatment applied. IBA concentrations modified different equilibriums endogenous/ exogenous which controlled the stimulus of morphogenesis processes. Mitotic cellular division caused call genesis in the cut parts, which was considerably influenced by the IBA as well as the individual capacities of the genotype.

In Table 1 and 2, were presented rooting percentage, call genesis, the ratio $\mathrm{C} / \mathrm{R}$, and fall of the leaves \%. The first key issue involves identification of the endogenous capacity, followed by the methods of regeneration and propagation, which increase efficiency through the phytoregulators of callogenesis and hormonal acids as an exogenous factor Ismaili, et al. (2014). Varieties have the lowest average rooting to Control, $10.2 \%$, simultaneously with the great variation $\mathrm{CV}=56.1 \%$. Varieties have increased the percentage of rooting, when they are treated with Gel IBA 53.5\%, meanwhile, decreased variation between them until $\mathrm{CV}=31.7 \%$. IBA and IBA / ANA hydro alcoholic have stimulated rooting 47.2 and $45.8 \%$. The percentage of rooting and callus, they were in strong correlation and been added to proportionally.

Variance analysis, for the percentage of rooting, callus and percentage of defoliation, they have proved that the averages are different for $\mathrm{q}^{*}$, referred to Lsd. The average of the treatments was $39.1 \%$, stand Dev was 0.45, and $\mathrm{q}^{*}$ (Lsd) 3.91 alpha 0.05, Root mean square error 0.49 . This experiment confirmed that treatment IBA Gel, has expressed advantages versus other treatments. Karen $\mathrm{Cv}$. had the highest percentage of rooting $80.7 \%$. Performance analysis for the percentage of rooting has made the ranking of treatments: $I B A$ gel $>I B A$ ha $>I B A / A N A$ ha $>$ Control.

The analysis confirmed different average therefore the coefficient of variation was high, CV 20.7-56.1\%. According to more small differences certified are certified the best treatments. Has resulted, showed that varieties have different abilities for rooting and in this context are ranked: Karen $>$ Nisjot $>$ Mick $>$ Perper $>$ H.Himara $>K$ .Berati $>$ Bllanic. There has been a strong correlation between varieties and IBA $(r=$ 0.96).

According to the analysis of Treatment/Treatment, Tukey test certified, it has come to conclusion for an additional powerful effect with IBA Gel, because in each case of analysis Theoretic $F$ Prob $>F$ $<.0001 *$ was less than the ${ }^{\text {actual }} \mathrm{F} 606.19$, see Table-1 and Figure-1. 
Rooting percentage in correlation with varieties. The formation of primary roots is dedicated to the quality of the olive thus parenchyma cells are modified to meristematic cells. Radicals start appearing in the cell layer of sapwood, so parenchyma tic cells are modified to meristematic cells. Radicals have already appeared in the cell layer of sapwood next to the cambium always in the area of medullar ray, Fig-1 Hartmann, (1965). The degree of natural rhizogenesis displays considerable variation $(C V=56.1 \%)$, and has been influenced by the genetic features of the olive genotypes. Rhizogenesis of each genotype had specific ratios with Call genesis and primary material and proved to be the responsible genotype for this index. The lower the value of this ratio the better was the rhizogenic mass. With IBA concentration; Rhizogenesis callogenesis - primary material have the normal index 0.85 to 0.89 , while there are reports of negative control 0.09 to 0.37 . The ability to rooting of varieties is different and in correlation with the type of AIB that applied. Karen, Perper and Nisjot cultivars, they have a high percentage of rotting and significant changes with other varieties. Gel IBA3000ppm has stimulated better the rooting, in every variety and there were visible changes with other forms of hormones.

Clonex 3000ppm gel, has stimulated 53.5\% the rooting, IBA $3000 \mathrm{ppm}$ ha. $47.2 \%$, IBA/ANA ha. $45.8 \%$ and Control $10.5 \%$ and had this level of performance ranking: (Clonus > IBA $3000>$ Control). As seen, the treatments all forms of IBA $A_{S}$ have been visible changes with Control and this effect has been for any variety. There has been wide frequency amplitude of rooting. Karen and Nisjot cultivars have resulted in a high percentage of rotting 80.7 and $64.6 \%$, while Bllanic a very lower percentage, respectively $2.8-12.6 \%$. Bllanic variety has no positive reaction with any form of IBAs.
In this way, should be said that the varieties, (genetic characteristic) were important factors for the process of rotting.

During the rooting phases nebulization consisted in preserving on the leaf a liquid aril which reduces tissue temperature and transpiration. During the rooting phases there have been several physiological processes. Resistance leaf until the end of the process was different and in correlation with varieties. Leaves were important for photosynthesis, for food with carbon hydrates and the root system. Apical leaves have an important role for photosynthesis, but when they have fallen, they die in the same time of callus tissue and the totally green cuttings.

The fall leaf was not related to callus or stimulating hormone, because certain pieces have not rooted, but they have presented the leaves. The fall leaf was 23.5 to $30 \%$, table 2. Decline lower leaves have coincided with Gel IBA. Varieties with more leaf resistant have been the Karen, Nisjot and Mick. The largest defoliation was in Treatment Control $30 \%$. As seen, defoliation was quality varietal and in correlation with IBA, callus process and thermal regimes. Rhizogenesis has been closely related to IBA forms as well as to the individual characteristics of the genotype. When the index of the $\mathrm{R} / \mathrm{C}$ ratio was next to the value (1) it served as a proof for good rhizogenic mass.

In Table 1 and Figure 2. The average $\mathrm{R} / \mathrm{C}$ for seven varieties it is 0.26 for the Control. This value comes increased up to 0.68 (amplitude $30.5-91 \%$ ), when is applied IBA in its three forms. Varieties which have high-value ratio, they coincided with very good rooting percentage. After cicatrisation of the wound, a thickened and hardened tissue called "callus" is formed beneath the cut. 
Table.1 Statistical Data Analysis for the Main Treatments of IBAS, Rooting \%, Call Genesis \%, and Respective Stand Dev for Seven Olive Cultivars H.Himara, K.Berati, Nisjot, Perper, Karen,

Bllanic And Mick

\begin{tabular}{|c|c|c|c|c|c|c|c|c|}
\hline \multirow{2}{*}{$\begin{array}{r}\text { Treatmen } \\
\text { Variety }\end{array}$} & \multicolumn{2}{|c|}{ Control } & \multicolumn{2}{|c|}{ IBA (HA) } & \multicolumn{2}{|c|}{ ClonexIBA } & \multicolumn{2}{|c|}{ IBA/ANA } \\
\hline & $\begin{array}{l}\text { Rooting } \\
(\%)\end{array}$ & Call (\%) & $\begin{array}{l}\text { Rooting } \\
(\%)\end{array}$ & Call (\%) & $\begin{array}{l}\text { Rooting } \\
(\%)\end{array}$ & $\overline{\text { Call }(\%)}$ & $\begin{array}{l}\text { Rooting } \\
(\%)\end{array}$ & $\overline{\text { Call }(\%)}$ \\
\hline H.Himara & $\begin{array}{l}4.7 \pm 0.60 \\
\mathrm{r}\end{array}$ & $\begin{array}{l}43.3 \pm 0.70 \\
\mathrm{a}\end{array}$ & $\begin{array}{l}42.4 \pm 0.6 \\
0 \mathrm{j}\end{array}$ & $\begin{array}{l}23.8 \pm 1.0 \\
0 \mathrm{j}\end{array}$ & $\begin{array}{l}49.5 \pm 0.5 \\
0 \mathrm{~h}\end{array}$ & $\begin{array}{l}31.3 \pm 0.70 f \\
\mathrm{~g}\end{array}$ & $\begin{array}{l}39.6 \pm 0.40 \\
\mathrm{k}\end{array}$ & $\begin{array}{l}42.0 \pm 1.0 \\
0 \mathrm{a}\end{array}$ \\
\hline K.Berati & $\begin{array}{l}6.0 \pm 0.40 \\
\mathrm{r}\end{array}$ & $\begin{array}{l}39.0 \pm 1.00 \\
b\end{array}$ & $\begin{array}{l}37.4 \pm 0.1 \\
51\end{array}$ & $\begin{array}{l}33.4 \pm 0.4 \\
0 \text { ef }\end{array}$ & $\begin{array}{l}53.6 \pm 0.4 \\
0 \mathrm{f}\end{array}$ & $\begin{array}{l}36.6 \pm 0.60 c \\
d\end{array}$ & $\begin{array}{l}35.3 \pm 0.20 \\
\mathrm{~m}\end{array}$ & $\begin{array}{l}38.2 \pm 0.7 \\
5 \mathrm{~b} \mathrm{c}\end{array}$ \\
\hline Nisjot & $\begin{array}{l}14.3 \pm 0.7 \\
0 \text { op }\end{array}$ & $\begin{array}{l}24.0 \pm 0.60 \\
j\end{array}$ & $\begin{array}{l}63.2 \pm 0.8 \\
0 \mathrm{~d}\end{array}$ & $\begin{array}{l}17.6 \pm 0.6 \\
01\end{array}$ & $\begin{array}{l}64.6 \pm 0.4 \\
0 \mathrm{~d}\end{array}$ & $24.5 \pm 0.50 \mathrm{j}$ & $\begin{array}{l}63.8 \pm 0.40 \\
d\end{array}$ & $\begin{array}{l}27.1 \pm 0.5 \\
5 \mathrm{hi}\end{array}$ \\
\hline Perper & $\begin{array}{l}15.0 \pm 0.4 \\
0 \text { o }\end{array}$ & $\begin{array}{l}10.0 \pm 1.20 \\
0\end{array}$ & $\begin{array}{l}53.8 \pm 0.4 \\
0 \mathrm{f}\end{array}$ & $\begin{array}{l}19.2 \pm 0.8 \\
0 \mathrm{kl}\end{array}$ & $\begin{array}{l}57.2 \pm 0.4 \\
0 \mathrm{e}\end{array}$ & $\begin{array}{l}15.4 \pm 0.60 \\
\mathrm{mn}\end{array}$ & $\begin{array}{l}49.6 \pm 0.60 \\
h\end{array}$ & $\begin{array}{l}38.2 \pm 0.7 \\
5 \mathrm{bc}\end{array}$ \\
\hline Karen & $\begin{array}{l}18.0 \pm 0.3 \\
0 \mathrm{n}\end{array}$ & $\begin{array}{l}33.7 \pm 0.50 \\
\mathrm{e}\end{array}$ & $\begin{array}{l}75.5 \pm 0.5 \\
0 \mathrm{~b}\end{array}$ & $\begin{array}{l}13.3 \pm 0.7 \\
0 \mathrm{n}\end{array}$ & $\begin{array}{l}80.7 \pm 0.3 \\
0 \mathrm{a}\end{array}$ & $10.3 \pm 0.70 \mathrm{o}$ & $\begin{array}{l}70.4 \pm 0.60 \\
\text { c }\end{array}$ & $\begin{array}{l}20.5 \pm 0.5 \\
0 \mathrm{k}\end{array}$ \\
\hline Bllanic & $\begin{array}{l}2.8 \pm 0.70 \\
\mathrm{~s}\end{array}$ & $\begin{array}{l}25.5 \pm 0.50 \\
\text { ij }\end{array}$ & $\begin{array}{l}13.3 \pm 0.5 \\
0 \mathrm{pq}\end{array}$ & $\begin{array}{l}17.5 \pm 0.5 \\
0 \mathrm{~lm}\end{array}$ & $\begin{array}{l}17.8 \pm 0.5 \\
0 \mathrm{n}\end{array}$ & $\begin{array}{l}19.6 \pm 0.40 \\
\mathrm{kl}\end{array}$ & $\begin{array}{l}12.6 \pm 0.20 \\
\mathrm{n}\end{array}$ & $\begin{array}{l}28.4 \pm 0.5 \\
5 \mathrm{~h}\end{array}$ \\
\hline Mick & $\begin{array}{l}13.3 \pm 0.3 \\
0 \mathrm{pq}\end{array}$ & $\begin{array}{l}31.2 \pm 0.60 \\
\mathrm{~g}\end{array}$ & $\begin{array}{l}45.0 \pm 0.9 \\
0 \mathrm{i}\end{array}$ & $\begin{array}{l}18.6 \pm 0.6 \\
0 \mathrm{kl}\end{array}$ & $\begin{array}{l}51.6 \pm 0.3 \\
0 \mathrm{~g}\end{array}$ & $23.7 \pm 0.30 \mathrm{j}$ & $\begin{array}{l}49.6 \pm 0.21 \\
h\end{array}$ & $\begin{array}{l}35.5 \pm 0.5 \\
0 \mathrm{de}\end{array}$ \\
\hline
\end{tabular}

Levels not connected by same letter are significantly different

Table.2 The Average Data for Rooting \%, Call Genesis \%, Raporti R/C Dhe Defoliation \%, Seven Varieties of Olive and Analysis of Variable Density; the Average, Stand Dev and Cv

\begin{tabular}{|c|c|c|c|c|c|c|c|c|c|c|c|c|c|c|c|c|}
\hline \multirow{2}{*}{$\begin{array}{l}\text { Treat } \\
\mathrm{m}\end{array}$} & \multicolumn{4}{|c|}{ Control } & \multicolumn{4}{|c|}{ IBA (HA) } & \multicolumn{4}{|c|}{ Gel IBA } & \multicolumn{4}{|c|}{ IBA/ANA } \\
\hline & $\mathrm{R}$ & $\mathrm{C}$ & $\mathrm{R} / \mathrm{C}$ & D & $\mathrm{R}$ & $\mathrm{C}$ & $\mathrm{R} / \mathrm{C}$ & D & $\mathrm{R}$ & $\mathrm{C}$ & $\mathrm{R} / \mathrm{C}$ & D & $\mathrm{R}$ & $\mathrm{C}$ & $\mathrm{R} / \mathrm{C}$ & D \\
\hline $\begin{array}{l}\text { Variet } \\
\mathrm{y}\end{array}$ & & & & & & & & & & & & & & & & \\
\hline $\begin{array}{l}\text { Himar } \\
\text { a }\end{array}$ & 4.7 & $\begin{array}{l}48 . \\
0\end{array}$ & $\begin{array}{l}0.0 \\
9\end{array}$ & 37 & $\begin{array}{l}42 . \\
4\end{array}$ & $\begin{array}{l}66 . \\
2\end{array}$ & $\begin{array}{l}0.6 \\
3\end{array}$ & 35 & $\begin{array}{l}49 . \\
5\end{array}$ & $\begin{array}{l}80 . \\
8\end{array}$ & $\begin{array}{l}0.6 \\
2\end{array}$ & 29 & $\begin{array}{l}39 . \\
6\end{array}$ & $\begin{array}{l}81 . \\
6\end{array}$ & 0.49 & 40 \\
\hline $\begin{array}{l}\text { K.Ber } \\
\text { ati }\end{array}$ & 6.0 & $\begin{array}{l}45 . \\
0\end{array}$ & $\begin{array}{l}0.1 \\
3\end{array}$ & 48 & $\begin{array}{l}37 . \\
4\end{array}$ & $\begin{array}{l}70 . \\
8\end{array}$ & $\begin{array}{l}0.5 \\
2\end{array}$ & 42 & $\begin{array}{l}53 . \\
6\end{array}$ & $\begin{array}{l}90 . \\
2 .\end{array}$ & 0.6 & 34 & 35. & 73. & 0.47 & 36 \\
\hline Nisjot & $\begin{array}{l}14 . \\
3\end{array}$ & $\begin{array}{l}38 . \\
3\end{array}$ & $\begin{array}{l}0.3 \\
7\end{array}$ & 15 & $\begin{array}{l}63 . \\
2\end{array}$ & $\begin{array}{l}80 . \\
8\end{array}$ & $\begin{array}{l}0.7 \\
8\end{array}$ & 16 & $\begin{array}{l}64 . \\
6\end{array}$ & $\begin{array}{l}89 . \\
1\end{array}$ & $\begin{array}{l}0.7 \\
3\end{array}$ & 12 & $\begin{array}{l}63 . \\
8\end{array}$ & $\begin{array}{l}91 . \\
0\end{array}$ & 0.7 & 17 \\
\hline Perper & 15. & $\begin{array}{l}25 . \\
0\end{array}$ & 0.6 & 27 & $\begin{array}{l}53 . \\
8\end{array}$ & $\begin{array}{l}64 . \\
0\end{array}$ & $\begin{array}{l}0.8 \\
4\end{array}$ & 25 & 57. & $\begin{array}{l}72 . \\
6\end{array}$ & $\begin{array}{l}0.7 \\
9\end{array}$ & 19 & $\begin{array}{l}49 . \\
6\end{array}$ & $\begin{array}{l}87 . \\
8\end{array}$ & 0.57 & 25 \\
\hline Karen & $\begin{array}{l}18 . \\
0\end{array}$ & $\begin{array}{l}48 . \\
7\end{array}$ & 0.4 & 11 & $\begin{array}{l}75 . \\
5\end{array}$ & $\begin{array}{l}88 . \\
8\end{array}$ & $\begin{array}{l}0.8 \\
5\end{array}$ & 13 & $\begin{array}{l}80 . \\
7\end{array}$ & 91 & $\begin{array}{l}0.8 \\
9\end{array}$ & 9 & $\begin{array}{l}70 . \\
4\end{array}$ & $\begin{array}{l}90 . \\
9\end{array}$ & 0.78 & 14 \\
\hline $\begin{array}{l}\text { Bllani } \\
\text { c }\end{array}$ & 2.8 & $\begin{array}{l}28 . \\
3\end{array}$ & 0.1 & 56 & $\begin{array}{l}13 . \\
3\end{array}$ & $\begin{array}{l}30 . \\
5\end{array}$ & $\begin{array}{l}0.4 \\
3\end{array}$ & 61 & $\begin{array}{l}17 . \\
8\end{array}$ & $\begin{array}{l}37 . \\
4\end{array}$ & $\begin{array}{l}0.4 \\
8\end{array}$ & 50 & $\begin{array}{l}12 . \\
6\end{array}$ & $\begin{array}{l}41 . \\
0\end{array}$ & 0.31 & 55 \\
\hline Mick & $\begin{array}{l}13 . \\
3\end{array}$ & $\begin{array}{l}44 . \\
5\end{array}$ & 0.3 & 16 & $\begin{array}{l}45 . \\
0\end{array}$ & $\begin{array}{l}63 . \\
6\end{array}$ & $\begin{array}{l}0.7 \\
1\end{array}$ & 19 & $\begin{array}{l}51 . \\
6\end{array}$ & $\begin{array}{l}75 . \\
3\end{array}$ & $\begin{array}{l}0.6 \\
9\end{array}$ & 12 & $\begin{array}{l}49 . \\
6\end{array}$ & $\begin{array}{l}85 . \\
1\end{array}$ & 0.59 & 18 \\
\hline Mean & $\begin{array}{l}10 . \\
5\end{array}$ & $\begin{array}{l}40 . \\
1\end{array}$ & $\begin{array}{l}0.2 \\
6\end{array}$ & 30 & $\begin{array}{l}47 . \\
2\end{array}$ & $\begin{array}{l}66 . \\
3\end{array}$ & $\begin{array}{l}0.6 \\
8\end{array}$ & 30 & $\begin{array}{l}53 . \\
5\end{array}$ & $\begin{array}{l}76 . \\
6\end{array}$ & $\begin{array}{l}0.6 \\
8\end{array}$ & $\begin{array}{l}23 . \\
5\end{array}$ & $\begin{array}{l}45 . \\
8\end{array}$ & $\begin{array}{l}78 . \\
7\end{array}$ & 0.55 & 29.2 \\
\hline $\begin{array}{l}\text { Std } \\
\text { Dev }\end{array}$ & 5,9 & $\begin{array}{l}10 . \\
0\end{array}$ & $\begin{array}{l}0.1 \\
8\end{array}$ & 17 & 9.8 & $\begin{array}{l}13 . \\
3\end{array}$ & $\begin{array}{l}0.1 \\
6\end{array}$ & 12 & 17 & $\begin{array}{l}14 . \\
7\end{array}$ & $\begin{array}{l}0.1 \\
3\end{array}$ & $\begin{array}{l}11 . \\
9\end{array}$ & $\begin{array}{l}12 . \\
1\end{array}$ & $\begin{array}{l}15 . \\
7\end{array}$ & 0.15 & 13 \\
\hline $\mathrm{CV}$ & $\begin{array}{l}56 . \\
1\end{array}$ & $\begin{array}{l}25 . \\
0\end{array}$ & 62 & 56 & $\begin{array}{l}20 . \\
7\end{array}$ & $\begin{array}{l}20 . \\
0\end{array}$ & $\begin{array}{l}23 . \\
5\end{array}$ & 40 & $\begin{array}{l}31 . \\
7\end{array}$ & $\begin{array}{l}19 . \\
1\end{array}$ & 19 & $\begin{array}{l}50 . \\
6\end{array}$ & $\begin{array}{l}26 . \\
4\end{array}$ & 20 & 27 & 44.5 \\
\hline
\end{tabular}


Figure.1 Dendrograme Onevay Analysis of Rooting by Treatment for Testing the Variability Analyzed All Pairs Tukey-Kramer Lsd 3.91, F Ratio 606.19, Prob > F <.0001*

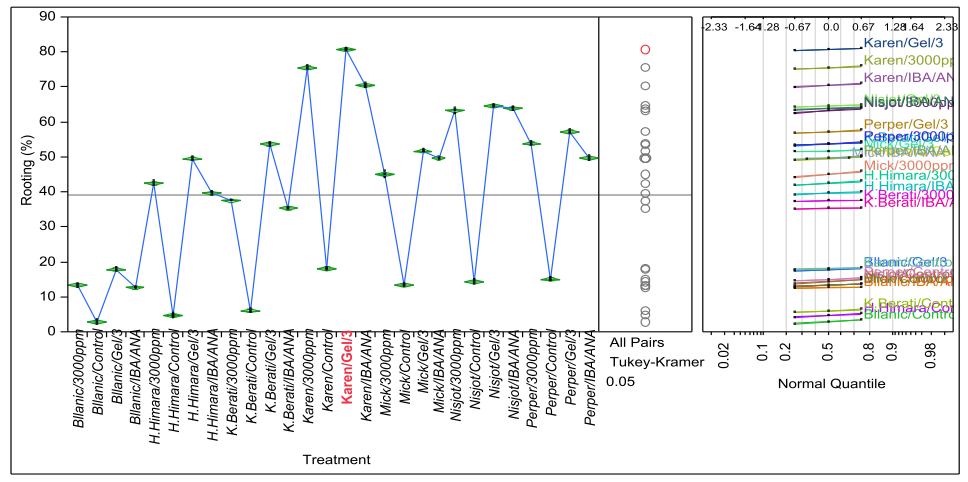

Figure.2 Report R/C to Root Cuttings (R) Versus Cuttings Callus (C) As the Average f Treatments Applied for Seven Autochthonous Olive

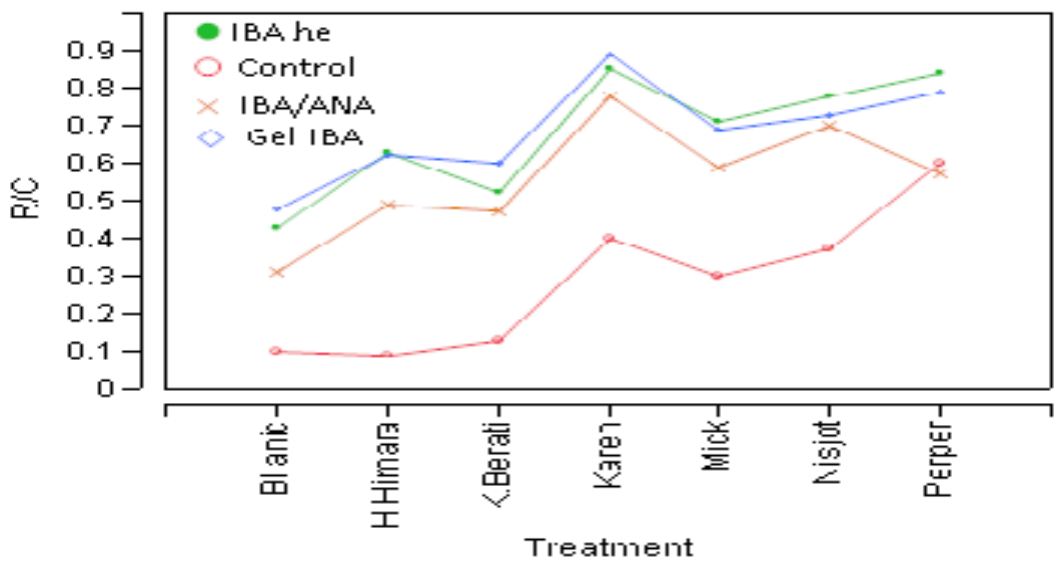

This tissue was regenerated at the cut or all over the segment of the intermodal segment of the base, two weeks later until complete induction for 35 days, Fig-1. The callus has resulted from cellular parenchyma reproduction of the cortex and phloem, expanded internal and external to the sclerenchyma tic ring. The well- formed callus seems opalescent to ochre and of different dimensions, Fig-2 and table-2 it is obvious that Control had poor and slow call genesis (40.1\%). The genotypes with the presence of IBA reinforced the effect of call genesis, caused rapid cellular propagation and differentiated voluminous callus. IBA/ANA 3000ppm, which was dot not result really favourable for rhizogenesis, has in any case caused a considerable call genesis mass. Rhizogenesis has been closely related to IBA as well as to the individual characteristics of the genotype.

The genotypes with the presence of $I B A$ reinforced the effect of call genesis, caused rapid cellular propagation and differentiated voluminous callus. IBA/ANA $h a$. which was dot not result really favorable for rhizogenesis, has in any case caused a considerable call genesis mass. The best results for the rooting percentage coincide with the period when intensive growth becomes vegetative. None differentiating of 
the roots is a genetic characteristic and happens as a result of the lack of the enzyme activators that synthesize the auxinic complexes assimilated by the phloem Wiesman, (1987).

Finally we can say that: The quality of rooting is related to the genetic nature of the cultivar in general and that of the cell in particular. There are some cultivars where the mitotic roots are developed all over the length of the internodes corresponding to the primary radiuses from which they derive.

In conclusion, the olive green cuttings they showed different abilities for their rooting and they are influenced; by varietal genetic factor, IBA and the rooting ambient. Olive cultivars have displayed an increase of the rhizogenous activity when they were treated with indole- 3 butyric acid in any quality.

The percentage of the rooting has wide amplitude and three commercial forms of AIB have stimulated in different ways this process.

Existence of leaves in the green cuttings, it was better when they are treated with gel clonus, simultaneously, it had the highest percentage of rooting. In this way is highlighted the importance of the presence of leaf for this method of multiplication. IBA, despite its forms has stimulated in each case rooting compared to control. During rhizogenous, morphological changes have been accompanied with several relations among the factors and cultivars.

\section{References}

Bartolini, G., Fabbri, A., Tattini, A. 1988. Phenolic acids and rhizogenesis in cuttings of "Frangivento" olive. Olea, 19 pp.73-77.

Berthon, J.Y., Battraw, M.J., Gaspar, J.,
Boyer, N. 1993. Early test using phenolic compounds and peroxidase activitiy to improve in vitrorooting of Sequoiadendron giganteum. Societe. Bot., 24: 7-13.

Caballero, J.M., Rallo, L. 1977. Duracion del periodo de enraizamento del olivo (Olea europea) por estaquillado semilenoso bajo nebulizacion. Olea, 2: 29-39.

Cantini, C., Cimato, A., Sani, G. 1999. Morphological evaluation of olive germplasm present in Tuscany region. Euphytica, 109(3): 173-181.

Daoud, A., Aghaj, T., Abu-Lebda, K.H., Alkhariat, M.S. 1989. Incidence de l'AIB sur l'enracinement des boutures feuillées d'olivier. Olivae, (27): 28-30.

Hartmann, T. 1952. Further Studies on the propagation of the olive by cuttings. Proc. Amer. Soc. Hort. Sci., (59): 155-160.

Hartmann, H.T., Loreti, F. 1965. Seasonal variation in rooting leafy olive cuttings under mist. Proc. Am. Soc. Hort. Sci., 87: 194-198.

Ismaili, H., Llanaj, Ll., Prifti, R. 2014: Propagation of Albanian olive varieties. J. Endocytobiosis and Cell Res., v. 25 p. 47-52.

Ismaili, H., Cakalli, A. 2014. Callogenesis and the influence of IBA on rhizogenesis of olive green parts. Albanian J. Agric. Sci. ISSN: 22182020. Volume 13, Special issue (2014) pp. $75-79$.

Ismaili, H. 2010. The influence of indole buturic acid (IBA) in different concentrations in the percentage of olive cv. Rooting in Albania. AlbShkenca, ALPA 2010 (5) 321.

Jmp, S.A.S. 2008. Statistical Analysis with Software. Version 6. Institute Inc. Cary. SAS Users Guide.

Fabbri, A. 1980. Influenza di alcuni caratteri 
anatomici sulla radicazione di talee di olivo cv "Frangivento". Riv. Ortoflorofrutt Ital., 64: 325-335.

Fernandes-Serrano, J.M., Serrano, M.C., Amaral, E. 2002. Effect of different hormone treatments on rooting of Olea europaea cv Galega vulgar cuttings. Acta. Hort., 586: 875-877.

Fiorino, P., Cimato, A. 1980. Stato attuale delle conoszenze sulla moltiplicazione dell'olivo con la tecnica della nebulizzazione. L'informatore agrario, 38: 12-30.
Loreti, F., Hartmann, H.T. 1964. Propagation of olive trees by rooting leafy cuttings under mist. Proc. Am. Soc. Hort. Sci., 85: 257-264.

Rodríguez, F., Guzmán, J.L., Berenguel, M., Arahal, M.R. 2008. Adaptive hierarchical control of greenhouse crop production. Int. J. Adap. Cont. Signal Process, 22: 180-197.

Wiesman, Z., Epstein, E. 1987. Metabolism and transport of 5-Hindole-3-butyric acid in cuttings of olive. Olea, 18: 29-33.

\section{How to cite this article:}

Hairi Ismaili. 2016. Study of Some forms of IBA in the Rooting Process of the Olive. Int.J.Curr.Microbiol.App.Sci. 5(3): 239-246. doi: http://dx.doi.org/10.20546/ijcmas.2016.503.029 